Bangladesh J. Bot. 48(2): 339-343, 2019 (June)

\title{
CHEMICAL COMPOSITION OF ESSENTIAL OILS OF BERRIES OF JUNIPERUS MACROCARPA SIBTH. \& SM. FROM TURKEY
}

\author{
Nedret Şengonca Tort, Hatice Demiray*, Aykut Güvensen \\ and Aylin Eşiz Dereboylu \\ Department of Biology, Section of Botany, Faculty of Science, University of Ege, 35100, \\ Bornova-Izmir/Turkey
}

Keywords: Juniperus macrocarpa, Berries, Chemical composition, Essential oil

\begin{abstract}
The chemical compositions of the hydrodistilled essential oils of ripen and unripen berries of Juniperus macrocarpa Sibth. \& Sm. (Jom) were analysed by GC-MS. Thirty eight compounds were identified from unripe berries, accounting for approximately $0.03 \%$ oil yield (v/w dried weight) and 16 compounds from ripe berries with $0.003 \%$ oil yield (v/w dried weight). While the major compounds in the essential oils of unripe berries were $\alpha$-cedrol $(30.04 \%), \alpha$-pinene $(18.81 \%)$, germacrene-D $(14.58 \%), \delta$-cadinene $(3.80 \%), \gamma$-cadinene (2.29\%), $\alpha$-humulene $(2.29 \%), \quad \gamma$-muurolene $(2.27 \%)$, epi-bicyclosesquiphellandrene (1.69\%), transcaryophyllene $(1.68 \%)$, valencen $(1.53 \%)$ and $\alpha$-cedrol $(49.87 \%), \beta$ - caryophyllene $(29.57 \%)$, $\alpha$-cedrene $(4.75 \%), \gamma$-muurolene $(2.54 \%)$, carvacrol methyl ether $(1.4 \%)$, trans-pinocarveol $(1.2 \%), \alpha$-pinene $(1.13 \%)$, $\alpha$-muurolene $(1.04 \%)$ were identified from ripe berries and their mean percentage varied according to their phenological stage. Both qualitative and quantitative differences between ripe and unripe berries of the plant were observed.
\end{abstract}

\section{Introduction}

The genus Juniperus $\mathrm{L}$. has a total of 52 species, with the majority in the temperate zone of the northern hemisphere of the world and 11 taxa including 8 species and three subspecies in Turkey. Juniperus oxycedrus L. (Cupressaceae) (prickly juniper, plum juniper, cade juniper, redberry juniper, cada) is a shrub or small tree native across to the Mediterranean region from Morocco and Portugal east to western Caucasus, growing on a variety of rocky sites from sea level up to $1600 \mathrm{~m}$ altitude (Orhan et al. 2011). Three subspecies: oxycedrus, macrocarpa (Sm.) Ball and badia (H. Gay) Debeaux of J. oxycedrus are mentioned in the Flora Europea; in the Flora of Turkey two subspecies, oxycedrus (Joo) and macrocarpa (Jom) were found (Amaral-Franco 1993, Farjon 2000). After the revision studies made in Turkey, the subspecies known as macrocarpa has been changed to species epithet (Kandemir 2018). Juniperus false fruits, female cones improperly called "berries" - are used as spice, mainly in European cuisine; they are used in Northern European and particularly Scandinavian cuisine to impart a sharp, clear flavour to meat dishes (Loizzo et al. 2007). Taviano et al. (2013) indicated the phenolic profile and some biological properties of the ripe "berries" methanol extracts of Joo and Jom from Turkey as threefold higher in Jom (17.89 $\pm 0.23 \mathrm{mg} \mathrm{GAE} / \mathrm{g}$ extract) than in Joo $(5.14 \pm 0.06 \mathrm{mg} \mathrm{GAE} / \mathrm{g}$ extract). In folk medicine $J$. oxycedrus berries have widely been used in the treatment of gastrointestinal disorders, common colds, as expectorant in cough, to treat calcinosis in joints and as diuretic to pass kidney stone, against urinary inflammations, hemorrhoids, and as hypoglycemic; leaves and berries are applied externally for parasitic disease (Sezik et al. 1997, Loizzo et al. 2007, Akkol et al. 2009). Leaves, resin, bark and berry extracts of J. oxycedrus were found to inhibit the growth of numerous microorganisms (Karaman et al. 2003). At the same time, J. oxycedrus is commonly used for the preparation of traditional medicinal brandy in Dalmatia (Öztürk et al. 2011). In

*Author for corresponce: <haticedemus@yahoo.com>. 
Turkey, Joo berries are consumed for treatment of diabetes; while powdered berries and leaves are used internally as tea (Orhan et al. 2012).

Although Jom has been reported to have a variety of uses in studies conducted in different countries, the essential oil composition of fruits harvested from Turkey is not found in any study. The essential oil composition of leaf samples harvested from different months of plants collected from the Ciftlik Village in Cesme - Izmir, Turkey, which is very close to the area fruit samples, were collected and it was revealed in a study conducted by Sezik et al. (2005). Because the berries of Jom are eaten in Turkey (Öztürk et al. 2011), and in folk medicine the ripe berries of this species were used as diuretic to pass kidney stones. In the present experiment the essential oils of the ripen and unripen berries of Jom growing in Turkey were focused and their chemical competitions were determined.

\section{Materials and Methods}

The ripe and unripe berries of Jom were collected in Izmir (Çeşme, around Ilıca-Altınyunus). The taxonomic identification of the plant materials was confirmed by Prof. Aykut Güvensen at the Department of Botany, Ege University, Turkey. Voucher specimens of Jom are deposited in the Herbarium (AEF 23799 and AEF 23855) of the Faculty of Science, Ege University.

The ripe berries without seeds were dried at room temperature ( 8 days, $200 \mathrm{~g}$ ) and steamdistilled for 8 hrs using a circulatory Clevenger-type apparatus (Adams 1991). The essential oil was recovered with diethyl ether, dried over anhydrous sodium sulfate, concentrated under a gentle stream of nitrogen and stored under nitrogen at $-20^{\circ} \mathrm{C}$ until analyzed $(0.006 \%$ yield). Airdried unripe berries ( 8 days, $100 \mathrm{~g}$ ) were grounded and distilled for $8 \mathrm{hrs}$. The essential oil was recovered in the same manner as above $(0.03 \%$ yield).

Qualitative data were determined by gas chromatography and mass spectrometry. Gas chromatography analyses were carried out on Hewlett Packard 6890 gas chromatograph coupled with HP 5973 MS dedector capillary column (HP 1909IZ-102) $(25 \mathrm{~m} \times 200 / \mu \mathrm{m})$, film thickness $0.33 / \mu \mathrm{m}$. Oven temperature program of $50 / 300^{\circ} \mathrm{C}$ at $10^{\circ} \mathrm{C} / \mathrm{min}$, carrier gas, helium, $2 \mathrm{ml} / \mathrm{min}$, autoinjection (Agilent 6890 ) temperature: $150^{\circ} \mathrm{C}$, FID detector temperature: $250^{\circ} \mathrm{C}$, 'split mode' ratio of $1: 30$ with hexane with volüme/ $\mu$. The identification of components was done with the use of the volatile oil LIBR (TP) library coupled with retention indices of reference compounds (Adams 1995) and built-in Wiley 275 library search systems comparing with standard essential oils data in ARGEFAR essential oil library of Ege University. Quantitative data (percentage composition) were determined from the GC peak areas without correction factors.

\section{Results and Discussion}

Table 1 shows sum up the yields (v/w, dried weight) of essential oil and chemical content (\% w/w) of the different samples of Juniperus. The yield obtained from the unripen berries of $J$. macrocarpa was $0.03 \%$ (100 g berry), while ripe berries exhibited a lower yield with $0.006 \%$ (200 $\mathrm{g}$ berry) by Clavenger method. In the results of present study, the content of monoterpenes was lower in the ripe berries $(5.15 \%)$ than in unripe berries $(20.9 \%)$ with higher $(1.2 \%)$ oxygenated monoterpene content in ripe berries $(1.11 \%)$. Generally, the maximum yields were obtained by distilling ripe berries of $J$. phoenicea ssp. turbinata and J. communis except for J. oxycedrus ssp. oxycedrus (Joo), whose maximum yield was obtained by distilling unripe berries. The content of monoterpenes was lower in the ripe and unripe berries (81.88 and $83.51 \%$, respectively) than in the leaves $(95.58 \%)$ and sesquiterpenes were higher in ripe and unripe berries, (14.79 and 13.89\%, respectively) than in the leaves $1.00 \%$ (Angioni et al. 2003). Sesquiterpenes was lower (65.23\%) content in unripe berries, while $(90.66 \%)$ were present in ripe berries of Jom. Also in this study, 
Table 1. Percentage composition of essential oil of dry ripen and unripen fruits of J. macrocarpa.

\begin{tabular}{|c|c|c|c|c|c|}
\hline \multirow[t]{2}{*}{ Compounds } & \multicolumn{2}{|r|}{$\mathrm{RI}_{\mathrm{a}}$} & \multicolumn{2}{|c|}{$\%$ content } & \multirow{2}{*}{$\begin{array}{c}\text { Identification } \\
\text { method }\end{array}$} \\
\hline & Ripen & Unripen & Ripen & Unripen & \\
\hline \multicolumn{6}{|c|}{ Monoterpenes } \\
\hline$\alpha$-pinen & 1048 & 1017 & 1.13 & 18.81 & GC-MS \\
\hline Carvacrol methyl ether & 1522 & & 1.4 & & $"$ \\
\hline$\alpha$-campholene aldehyde & 1081 & 1592 & 0.96 & 0.22 & " \\
\hline$\alpha$-phellandrene & 1071 & & 0.93 & & $"$ \\
\hline Camphene & 1055 & 1049 & 0.43 & 0.09 & $"$ \\
\hline (1R)-(-)-myrtenal & 1178 & & 0.30 & & " \\
\hline 3-carene & & 1034 & & 1.01 & $"$ \\
\hline$\beta$ - pinen & & 1080 & & 0.55 & $"$ \\
\hline$\alpha$-terpinolene & & 1525 & & 0.17 & $"$ \\
\hline Sabinene & & 1019 & & 0.05 & $"$ \\
\hline \multicolumn{6}{|c|}{ Oxygenated monoterpenes } \\
\hline Trans-pinocarveol & 1027 & 1554 & 1.2 & 0.54 & GC-MS \\
\hline 3-thujen 2-ol & & 1538 & & 0.23 & GC-MS \\
\hline Caryophyllene oxide & & 1573 & & 0.34 & GC-MS \\
\hline \multicolumn{6}{|c|}{ Sesquiterpenes } \\
\hline$\alpha$ - cedrol & 1583 & 1563 & 49.87 & 30.04 & GC-MS \\
\hline$\beta$-caryophyllene & 1505 & & 29.57 & & " \\
\hline$\alpha$-cedrene & 1087 & & 4.75 & & $"$ \\
\hline$\gamma$-muurolene & 1535 & & 2.54 & & $"$ \\
\hline$\alpha$ - cubabene & 1580 & 1082 & 0.98 & 0.17 & $"$ \\
\hline$\alpha$-muurolene & 1025 & & 1.04 & & $"$ \\
\hline D-germacrene & 1510 & 1568 & 0.90 & 14.58 & $"$ \\
\hline Cuparene & 1543 & & 0.58 & & $"$ \\
\hline Calacorene & 1551 & & 0.43 & & $"$ \\
\hline$\delta$ - Cadinene & & 1549 & & 3.80 & $"$ \\
\hline$\beta$-Cubenene & & 1062 & & 0.66 & $"$ \\
\hline Copaene & & 1567 & & 0.54 & $"$ \\
\hline (-)-Thujopsen & & 1583 & & 0.49 & $"$ \\
\hline$\beta$-silinene & & 1575 & & 0.45 & $"$ \\
\hline$\alpha$-humulene & & 1548 & & 2.29 & $"$ \\
\hline Cadına-1,4 diene & & 1518 & & 0.39 & $"$ \\
\hline$\alpha$-longipinene & & 1525 & & 0.37 & $"$ \\
\hline$\gamma$-muurolene & & 1568 & & 2.27 & " \\
\hline epi-bicyclosesquiphellandrene & & 4520 & & 1.69 & $"$ \\
\hline trans-caryophyllene & & 1544 & & 1.68 & $"$ \\
\hline Valencen & & 1542 & & 1.53 & $"$ \\
\hline$\alpha$-amorphene & & 1528 & & 1.12 & $"$ \\
\hline Bicyclo germacrene & & 1557 & & 1.04 & $"$ \\
\hline$\alpha$-ylangene & & 1538 & & 0.66 & $"$ \\
\hline trans- $\alpha$-bergamotene & & 1575 & & 0.29 & $"$ \\
\hline +calerene & & 1029 & & 0.26 & $"$ \\
\hline Salvial-4(14)-en-1-one & & 1837 & & 0.22 & $"$ \\
\hline$\alpha$-copaene & & 1508 & & 0.21 & $"$ \\
\hline Limonene & & 1077 & & 0.19 & $"$ \\
\hline Germacrene & & 1518 & & 0.12 & $"$ \\
\hline$\beta$-phellandrene & & 1015 & & 0.09 & " \\
\hline$\gamma$-elemene & & 1538 & & 0.08 & $"$ \\
\hline
\end{tabular}

$a$ Retention indices in elution order from DB-5 colum. 
sesquiterpenes were higher in ripe and unripe berries (90.66 and $65.23 \%$, respectively) than monoterpenes (5.15 and $20.9 \%$, respectively). In all samples, $\alpha$-cedrol $(49.87 \%)$ was the main component in ripe berries, and $30.04 \%$ in unripe berries while $\alpha$-pinene was the main component (85.95\% in leaves, $70.64 \%$ in ripe berries and $62.26 \%$ in unripe berries) in Joo (Angioni et al. $2003)$. In the present results $\alpha$-pinene, $\alpha$-campholene aldehyde, trans-pinocarveol, camphene, $\alpha$ cubabene, germacrene- $d, \alpha$-cedrol and $\gamma$-muurolene were similar in all berries. $\alpha$-cedrol was higher in the ripe berries than unripe ones (49.87 versus $30.04 \%$ ). The content of $\alpha$-pinen was higher in unripe berries than ripe berries (18.81\% versus $1.13 \%)$ of $J$. macrocarpa. D-germacrene was higher in the unripen berries than ripen ones $(14.58$ versus $0.90 \%)$. Trans-pinocarveol was higher in ripe berries than unripe berries $(1.2$ versus $0,54 \%)$ of Jom. In the present study $\beta$-pinen, sabinene, 3 -carene, limonene, $\beta$-phellandrene, $\alpha$-terpinolene, $\alpha$-copaene, trans- $\alpha$-bergamotene, germacrene, trans-caryophyllene, (-)-thujopsen, +calerene, $\beta$-cubanene, 3-thujen 2 -ol, $\alpha$-humulene, $\alpha$-amorphene, bicyclo germacrene, $\gamma$-elemene, $\delta$-cadinene, $\gamma$-cadinene, cadina-1,4 diene, copaene, valencene, caryophyllene oxide, salvial-4(14)-en-1-one, $\alpha$-ylangene, limonene, $\beta$-silinene, $\alpha$ longipinene, epi-bicyclosesquiphellandrene, trans-caryophyllene, solanesol were only found in unripe berries of $J$. macrocarpa, while $\alpha$-cedrene, carvacrol methyl ether, (1R)-(-)-myrtenal, $\alpha$ phellandrene, $\alpha$-muurolene, cuparene, calacorene, $\beta$-caryophyllene were found in ripe berries of $J$. macrocarpa.

The seasonal differences of oils of Jom leaves were $84.6 \%$, in May, 95.2\% in August, and $90.1 \%$ in October samples rich in manoyl oxide $(7.7-21.9 \%), \alpha$-pinene $(7.2-11.1 \%), \alpha$-cedrol (2.3 - 9.7\%), widdrene $(2.1-5.7 \%), \alpha$-muurolene $(4.1-4.8 \%)$, trans-verbenol $(1.7-4.3 \%)$, germacrene $\mathrm{D}(1.5-4.1 \%), \delta$-cadinene $(3.2$ - $3.8 \%), \alpha$-campholene aldehyde $(1.7-3.2 \%)$, transpinocarveol (1.5 - 3.0\%), cubebol (1.4 - 2.4\%), caryophyllene oxide $(1.5-1.9 \%)$, $\delta$-cadinene $(1.0$ $1.8 \%), \beta$-caryophyllene $(0.7-1.8 \%)$, and epi-cubebol (1.0 - 1.4\%). Main component of ripe and unripe berries was $\alpha$-cedrol (49.87 and $30.04 \%$, respectively), although it was present in August samples of leaves of the same species (Sezik et al. 2005). $\alpha$-cedrol ratio was; in May (2.3\%), in August (9.7\%) and in October (3.4\%) in the leaves of Jom likely as the berries of J. macrocarpa. Similarly in ripe berries $\alpha$-pinene content was higher than unripe berries of Tunusian Jom while myricene, $\beta$-phellandrene, $\beta$-pinene, respectively in unripe berries (Medini et al. 2010).

According to the present results, unripe berries were rich in $\alpha$-cedrol $(30.04 \%), \alpha$-pinene (18.81\%), germacrene-D (14.58\%); $\alpha$-cedrol (49.87\%), $\beta$-caryophyllene $(29.57 \%), \alpha$-cedrene $(4.75 \%)$ were identified from ripe berries. It was concluded that the yield and the composition of the $J$. oxycedrus essential oils depend on the origin of the plant; e.g. while the leaves from Elaphonios (Greece) were rich in $\alpha$-pinene (26.94\%) and $\alpha$-cedrole (13.88\%) (Stassi et al. 1995), $\alpha$-cedrol was shown only in berries of $J$. macrocarpa. $\beta$-Myrcene, $\alpha$-pinene, and DL-limonene and germacrene D were indicated in berries of different countries (Guerra-Hernandez et al. 1987, Cavaleiro 2001, Koukos et al. 2002, Salido et al. 2002, Valentini et al. 2003, Asllani 2004, Hajdari et al. 2014). The variations were related to genetic and climatic factors, soil conditions, phase of growth (vegetative or flowering stage), and part of the plant (Nemeth 2005).

\section{References}

Adams RP 1991. Cedar wood oil-analyses and properties. Modern Methods of Plant Analysis. Essential Oils and Waxes; Berlin (Germany). pp. 159-173.

Adams RP 1995. Identification of essential oil components by gas chromatography/mass spectroscopy. Allured Publishing Corporation; Illinois (ABD). pp. 31-53.

Akkol KE, Güvenç A and Yesilada E 2009. A comparative study on the antinociceptive and antiinflammatory activities of five Juniperus taxa. J. Ethnopharmacol. 125: 330-336.

Amaral-Franco J 1993. Juniperus L. Flora Europea vol. I; Cambridge (England). pp. 46-48. 
Angioni A, Barra A, Russo MT, Coroneo V, Dessi S and Cabras P 2003. Chemical composition of the essential oils of Juniperus from ripe and unripe berries and leavesand their antimicrobial activity. J. Agric. Food Chem. 51: 3073-3078.

Asllani U 2004. Essences of aromatic plants in Albania. In: Albanian: Esencat ebimëvearomatike të Shqipërisë. Tiranë pp. 276-283.

Cavaleiro CMF 2001. Óleos essenciais de Juniperus de Portugal. PhD thesis, Universidade de Coimbra, Faculdade de Farmácia, Coimbra, Portugal.

Farjon A 2000. Juniperus L. Flora of Turkey and the East Aegean Islands, vol. 11 (Suppl. 2). Edinburgh (England). pp. 8-10.

Guerra-Hernandez H, Carmen L and Garcia V 1987. Determination by gas chromatographyof terpenes in the berries of the species Juniperus oxycedrus L. and J. sabina L. J. Chromatogr. 396: 416-420.

Hajdari A, Behxhet M, Valmira G, Dashnor N, AlbaniI and Johannes N 2014. Chemical composition of the essential oils of ripe berries of Juniperus oxycedrus L., growing wild in Kosovo. Biochem. Syst. Ecol. 57: 90-94.

Karaman I, Sahin F,Güllüce M,Ogütçü H, Sengül M and AdigüzelA 2003. Antimicrobia activity of aqueous and methanol extracts of Juniperus oxycedrus L. J. Ethnopharmacol. 85: 231-235.

Kandemir A 2018. Juniperus L. In: Resimli Türkiye Floras1, Güner A, Kandemir A, Menemen Y, Y1ldırım H, Aslan S, Ekşi G, Güner I, Çimen AÖ, Eds, Ali Nihat Gökyiğit Vakfi, İstanbul (Türkiye). pp. 382408.

Koukos P, Papadopoulou K, Papagiannopoulos A and Patiaka D 2002. Variations in the chemical composition of the berry oil of Juniperus oxycedrus L. grown in North and West Greece. Holz als Roh Werkst. 60:152-153.

Loizzo MR, Tundis R, Conforti F, Saab AM, Statti GA and Menichini F 2007. Comparative chemical composition, antioxidant and hypoglycaemic activities of Juniperus oxycedrus ssp. oxycedrus L. berry and wood oils from Lebanon. Food Chem. 105: 572-578.

Medini H, Elaissi A, Khouja M L, Chraief I, Farhat F, Hammamic M, Chemlia R and Harzallah-Skhirie F 2010. Leaf essential oil of Juniperus oxycedrus L. (Cupressaceae) Harvested in Northern Tunisia: Composition and Intra-Specific Variability. Chem. Biodivers. 7: 1254-1265.

Nemeth E 2005. Essential oil composition of species in the genus Achillea. J. Essent. Oil Res. 17(5): 501512.

Orhan N, Orhan IE and Ergun F 2011. In sights into cholinesterase inhibitory and antioxidant activities of five Juniperus species. Food Chem. Toxicol. 49: 2305-2312.

Orhan N, Aslan M, Demirci B and Ergun F 2012. A bioactivity guided study on the antidiabetic activity of Juniperus oxycedrus subsp. oxycedrus L. leaves. J. Ethnopharmacol. 140: 409-415.

Öztürk M, Tümen I, Uğur A, Aydoğmuş-Öztürk F and Topçu G 2011. Evaluation of fruit extracts of six Turkish Juniperus species for their antioxidant, anticholinesterase and antimicrobial activities. J. Sci. Food Agric. 91: 867-876.

Salido S, Altarejos J, Nogueros M, Sanchez A, Pannecouque C, Witvrouw M and De Clercq E 2002. Chemical studies of essential oils of Juniperus oxycedrus ssp. badia. J. Ethnopharmacol. 81: 129-134.

Sezik E, Yesilada E, Tabata M, Honda G, Takahishi Y, Fujita T, Tanaka T and Takeda Y 1997. Traditional medicine in Turkey. VIII. Folk medicine in East Anatolia: Erzurum, Erzincan, Ağri, Kars, Iğdir Provinces. Econ. Bot. 51: 195-211.

Sezik E, Kocakulak E, Baser KHC and Ozek T 2005. Composition of the essential oils of Juniperus oxycedrus subsp. macrocarpa from Turkey. Chem. Nat. Compd. 41(3): 352-354.

Stassi V, Verykokidou E, Loukis A, Harvala A and Philianos S 1995. Essential oil of Juniperus oxycedrus. L. subsp. macrocarpa. (Sm.) Ball. J. Essent. Oil. Res. 7: 675-676.

Taviano MF, Andreana M, Ada T, Valentina B, Antonietta M, Paola D, Francesco C, Paola D, Luigi M, Aysegül G, Rita DP and Nataliziai M 2013. Juniperus oxycedrus L. subsp. oxycedrus and Juniperus oxycedrus L. subsp. macrocarpa (Sibth. \& Sm.) Ball. “berries”” from Turkey: Comparative evaluation of phenolic profile, antioxidant, cytotoxic and antimicrobial activities. Food. Chem. Toxicol. 58: 22-29.

Valentini G, Bellomaria B, Maggi F and Manzi A 2003. The leaf and female cone oils of Juniperus oxycedrus L. ssp. oxycedrus and J. oxycedrus ssp. macrocarpa (Sibth. et Sm.) Ball. from Abruzzo. J. Essent. Oil Res. 15: 418-421. 